\title{
Circadian rhythms: strong evidence on how to approach depression
}

\author{
Konstantinos N Fountoulakis \\ From $1^{\text {st }}$ International Congress on Neurobiology and Clinical Psychopharmacology and European \\ Psychiatric Association Conference on Treatment Guidance \\ Thessaloniki, Greece. 19-22 November 2009
}

It is widely accepted that mood disorders are related to biological rhythm abnormalities. It has been proved that this happens at least in a significant proportion of patients which profit from chronotherapeutic interventions. Rhythm abnormalities in mood disorders include among others diurnal mood variation, elevated nocturnal body temperature, lower nocturnal TSH, overall increased cortisol secretion, phase advance of cortisol and melatonin secration and sleep architecture abnormalities. The exact relationship of these abnormalities to the etiopathogenesis of depression remains unclear; it is however evident that at least some treatment modalities worsen rhythms, leave residual symptoms and therefore do not lead to full remission, which sould be the ultimate goal of any treatment approach. It seems important for an informed approach and understanding of mood disorders and their treatment to take into consideration the normalization and stabilization of endogenous rhythms.

Published: 22 April 2010

doi:10.1186/1744-859X-9-S1-S48

Cite this article as: Fountoulakis: Circadian rhythms: strong evidence on how to approach depression. Annals of General Psychiatry 2010 9(Suppl 1): 548.
Submit your next manuscript to BioMed Central and take full advantage of:

- Convenient online submission

- Thorough peer review

- No space constraints or color figure charges

- Immediate publication on acceptance

- Inclusion in PubMed, CAS, Scopus and Google Scholar

- Research which is freely available for redistribution

Submit your manuscript at www.biomedcentral.com/submit
C Biomed Central $3^{\text {rd }}$ Department of Psychiatry, School of Medicine, Aristotle University of Thessaloniki, Greece 